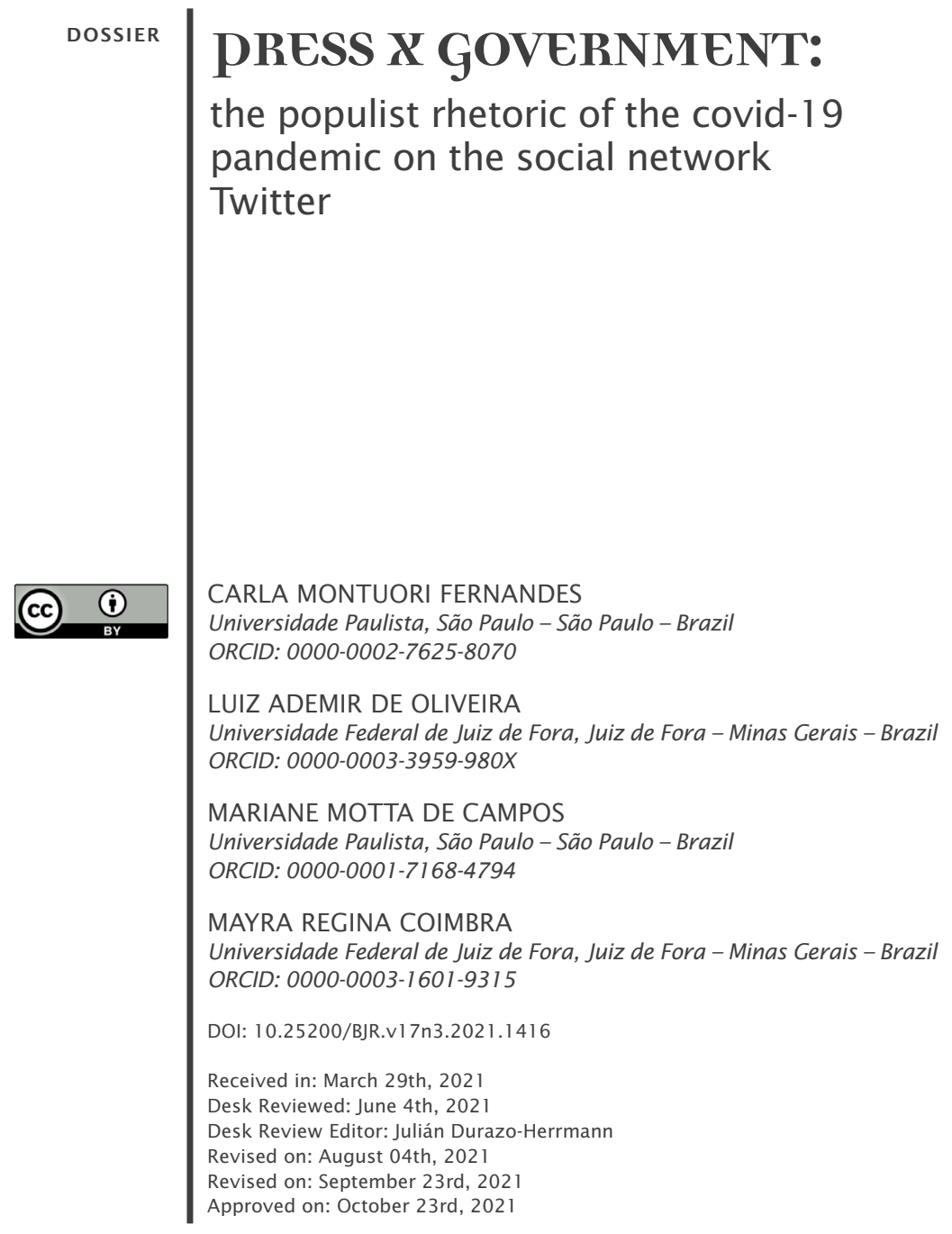


ABSTRACT - This paper begins with a discussion of the concept of populism in order to analyze how Jair Bolsonaro's criticisms of the press circulated on the social network Twitter at a time when Brazil had recorded the highest number of covidrelated deaths, in the first week of March 2021. This paper presupposes that the president's support network incorporated the populist binary rhetoric of "us" against a "corrupt elite" which is responsible for conspiring and amplifying the effects of the health crisis in the country. As a methodology, we opted for a mixed proposal based on content analysis and analysis of social networks. As a result, we found that the tweets from Bolsonaro supporters claim that the press is corrupt, and manipulates and harasses the president in its coverage of the pandemic.

Key words: Populism. Press. Jair Bolsonaro. Pandemic. Covid-19.

\section{IMPRENSA X GOVERNO: a retórica populista da pandemia da covid-19 na rede social Twitter}

RESUMO - O artigo parte da discussão do conceito de populismo, com o objetivo de analisar como as críticas de Jair Bolsonaro à imprensa circularam na rede social Twitter no momento em que o Brasil atingia o maior número de mortos pela covid-19, na primeira semana de março de 2021. O texto traz como hipótese que a rede de apoio ao presidente incorporou a retórica binarista do "nós" contra uma "elite corrupta" que é responsável por conspirar e ampliar os efeitos da crise sanitária no país. Como metodologia, optouse por uma proposta mista ancorada na análise de redes sociais e análise de conteúdo. Como resultado, constatou-se que os tweets dos apoiadores de Bolsonaro associaram a imprensa atributos de corrupção, manipulação e perseguição ao líder na cobertura contra uma "elite corrupta" e atribuiu à imprensa o caráter dos efeitos da pandemia.

Palavras-chave: Populismo. Imprensa. Jair Bolsonaro. Pandemia. Covid-19.

\section{PRENSA X GOBIERNO: la retórica populista de la pandemia covid-19 en la red social Twitter}

RESUMEN - Artículo de la discusión del concepto de populismo, con el fin de analizar cómo circularon en la red social Twitter el comunicado de prensa de Jair Bolsonaro al equipo Cuando Brasil alcanzó el mayor número de muertes por covid-19, en la primera semana de marzo de 2021. El texto plantea la hipótesis de que la red de apoyo al presidente incorporó la retórica del binarismo populista del "nosotros" frente a una "élite corrupta" y atribuyó a la prensa el carácter de enemigo del gobierno, responsable de conspirar y amplificar los efectos de la salud en el pais. Como metodología, optamos por una propuesta mixta anclada en el análisis de redes sociales y análisis de contenido. Como resultado, se encontró que los tuits de simpatizantes de Bolsonaro asociaron a la prensa con atributos de corrupción, manipulación y acoso al líder para cubrir los efectos de la pandemia.

Palabras clave: Populismo. Prensa. Jair Bolsonaro. Pandemia. Covid-19.

\section{Introduction}

In Laclau's (2005) writings on populism, he emphasizes that in order to understand the concept one must consider the political context in which the phenomenon emerges. He also points out that populists emerge in contexts of generalized dissatisfaction where traditional 
political parties are in crisis and/or have lost credibility with voters. An institutional crisis has been established on an international level, most notably since the second decade of the 21 st century, which has affected the democratic governments in several countries, reaffirming the perception that periods of populist upsurge are preceded or accompanied by institutional instability (Mouffe, 2000).

A new form of populism has emerged here, evidenced mainly by the rise of an international extreme right which focuses its discursive strategies on denying institutional politics, critiquing democratic institutions and the press, as well as promoting values of centralized power, militarism, masculinity, and nationalism, as evident in the rise of "Bolsonarism" in Brazil or Trumpism in the USA. Bolsonarism is an extreme right political phenomenon that erupted in Brazil with the rise of Jair Bolsonaro's popularity, especially during his presidential election campaign in Brazil in 2018.

Looking at Brazil, Bolsonaro won the presidency in 2018 amid a lack of credibility in the country's major political parties. Operation Car Wash identified political leaders from the PT, PSDB, and MDB parties and their involvement in large-scale corruption which discredited traditional politics. What's more, Bolsonaro's support of this Operation and his main agenda of fighting against corruption has led to a kind of separation from traditional politics, which are now referred to as "the old politics". Another important point regarding Bolsonaro's discourse is his attack on the country's traditional institutions, particularly media institutions.

The consolidation of the internet has established a new dynamic for politics. Cesarino (2020) points out that, in the predigital era, effective leadership depended heavily on a leader's abilities, on their ability to communicate with the public, and on the marketing team's ability to write discourses more aligned to the media. Digital populism, as described by Cesarino (2020), is structured by the consonance between the media apparatus (digital), the discursive mechanism (of mobilization), and a (political) tactic of building hegemony.

Therefore, according to this author, digital populism is not only defined by the insertion of digital technologies into the populist dynamic, but also by the inclusion of specific discursive patterns that are structured and permanently mobilized, creating conspiracy theories to attack a common "enemy". In digital populism, elites move outside political institutions and are envisioned as a cohesive, 
monolithic entity separate from the people yet ultimately one that decides their future. This was even more evident during the pandemic with Bolsonaro supporters.

As public health experts point out, Bolsonaro's negationist position and his failure to adopt social isolation measures triggered a serious covid-19 situation in Brazil; the country became the epicenter of the pandemic in 2021 , which experienced the third wave with covidrelated deaths reaching 300.000 in March of this year. The president also looks to create a sense of doubt about the data conveyed by traditional media regarding the number of infected people, the number of deaths, and the health crisis itself with the collapse of the country's public and private health system (Teófilo et al., 2021).

In order to identify aspects of digital populism, more specifically the "us" vs. "them" dynamic, an analysis was carried out on the 15 predominant tweets that support the president to ascertain how Bolsonaro supporters reacted to criticisms of Bolsonaro in the Brazilian press. It is noteworthy that the press's approach to this subject is listed only for mapping the network, highlighting the main clusters and tweets that mentioned Bolsonaro's discourse and were guided by newspapers, serving as a commentary for political activists and journalists.

In addition to establishing adversarial boundaries between friend and foe, populism creates a media channel that is capable of establishing an intimate relationship with its followers. One of the characteristics of this new populism is its strong connection with the digital universe. Gerbaudo (2018) proposes the concept of populism 2.0 where social networks are tools for an emerging mass digital antiestablishment policy.

In the field of politics, the shake-up of traditional institutions such as science and journalism has given an unprecedented space for the circulation of conspiracy theories and for the performance of a new type of political populism, one that manifests in the virtual environment of social media. Statements that frequently break from institutional norms and even scientific consensus can be found on social networks; they are an adequate channel to manifest populist rhetoric and for citizens to state their indignation on elites considered to be corrupt. In this sense, it is important to understand how the digital tactic of using narratives to gain a large group of online followers contributes to the growing disbelief in other institutions or social fields, leading to possible ruptures with democratic practices. 
In Brazil, Bolsonaro reveals concepts from a populism that have already been explained in the academic world but hardly studied in the country, such as the use of networks to promote the mobilization of online followers who attack their leader's political opponents.

The research is transdisciplinary; it is ample and is conducted from several approaches. First, it points out how the emergence of digital populism, in the form of Jair Bolsonaro, represents a crisis of the political system by questioning how democratic institutions operate. The strong climate of polarization that exists in Brazil also leads to disputes between those who hold right-wing populist narratives and those who defend representative democratic institutions.

Discussing this populist rhetoric surrounding the covid-19 pandemic held by Bolsonaro support groups allows us to analyze how these narratives came to be and how they are confronted by discourses of science and institutions. The media, as a reflection of social life, is an important barometer by which to understand these tensions between actors that dispute the hegemony of political power. In this sense, it is important to understand how the network of Bolsonaro supporters view the press as one of their main targets, especially during the pandemic where media outlets are disseminating science and giving science discourse a platform on which it can discredit the negationism adopted by the federal government.

This paper seeks to understand how the conversation on Twitter was built around President Bolsonaro's criticisms of the press between March 3 and 8, 2021, when Brazil reached its highest numbers of covid-related deaths since the beginning of the pandemic. This paper hopes to provide answers to the questions: to what extent does the network of support around the Brazilian president incorporate populist rhetoric of attacking media institutions, and how does the "people" vs. the "elite" binary outlook shift to the "press" vs. the "president" polarization?

The choice is justified by the fact that Twitter is one of the most influential social networks in the world due to its high capacity for sharing information in real-time and the wide political and social mobilization it has provided over the last couple of decades. Santaella and Lemos (2010) reiterate the importance of Twitter when they characterize it as a "social and political 'thermometer', an instrument of civil resistance, a cultural stage and an arena for continuous conversations" (p. 66). In terms of visibility, a survey published by the Digital 2019 report, from the website We are Social, points out that 
Twitter is the sixth most-used social network in Brazil, accessed by $43 \%$ of the active internet users. In addition, Bolsonaro uses Twitter to establish a constant dialogue with his group of supporters, and the space then becomes a conversation network that operates as a counterpoint to the press, becoming a privileged locus to question, respond to, and attack the "enemies" of the government.

To answer the survey questions, we collected a total of 2.500 Twitter comments posted on March 3rd, 5th, and 8th of 2021 , supported by the Netlytic data collection tool. A qualitative approach was carried out based on textual mining of fifteen tweets that had the greatest repercussion (those that had the greatest number of retweets). This data was supported by the Iramuteq software and interpreted from the perspective of automated content analysis (Cervi, 2018).

When analyzing the Bolsonaro supporter clusters that stood out the most in terms of criticizing the press, we observed that retweets were circulated with messages denouncing the manipulation of the press and listing the challenges that Bolsonaro faces in governing the country. Thus, the creation of conspiracy theories and the delegitimization of traditional media is evident (Cesarino, 2020). These analyses are clearer when presented through content analysis, which confirms the confrontation between the Bolsonaro support network and the press, which is classified from the populist perspective as an enemy of the Bolsonaro government.

\section{Contextualization of Jair Bolsonaro's clash with the press}

Bolsonaro's contentious relationship with the press is intensifying daily. As shown by numerous surveys conducted during the electoral process, Jair Bolsonaro built his campaign mostly on social media such as Facebook, Twitter and WhatsApp, avoiding exposure and attacking traditional media, especially those that did not agree with his discourse (Fenaj, 2019; Avritzer, 2020; Pereira, 2021).

The high point of this clash with traditional media groups was then-candidate Bolsonaro's reaction to accusations' made by the Folha de S.Paulo newspaper that certain companies were illegally funding up to 12 million reais to distribute messages in bulk over WhatsApp that opposed then PT candidate and main political opponent of Bolsonaro, Fernando Haddad. A report by journalist Patrícia Campos 
Mello labeled this as slush fund money, and in 2020, an Anti-Fake News Commission (CPI das Fake News) heard her testimony that she had become the target of sexist and misogynous insults and threats from the president.

Bolsonaro used Facebook to deny his involvement in these harmful schemes and accused Folha of "working for his opponent" in the second round of the presidential elections. A week before the election, Bolsonaro criticized $^{2}$ the newspaper on a live video address to his supporters, broadcast on large screens on Paulista Avenue, in the city of São Paulo. "Folha de S. Paulo is Brazil's biggest fake news source. You won't get any more advertising money from the federal government," he stated to excited cheers from supporters. "Venal press, my condolences".

His standpoint of avoiding traditional media was maintained on election day, October 28, 2018, when he made his first statement ${ }^{3}$ live via his social media pages, without the presence of the press. His first words as president were not spoken in a public place or inside his party headquarters, as is customary for election winners to do. They were spoken from his living room via Facebook Live ${ }^{4}$.

Imitating the strategy adopted by former US president Donald Trump, once elected, Bolsonaro adopted a standoffish position against media professionals and outlets that published unfavorable reports of him. Using one of Trump's favorite tactics, the Brazilian president also started using the term "fake news" to label news that he deemed was unfavorable toward him. In his first interview for a news program, Jornal Nacional aired on October 29, the president clashed with program host William Bonner. After being questioned about the verbal attacks he made on the Folha de S.Paulo newspaper, Bolsonaro said: "This newspaper is done". The strategy of governing without the intermediation of traditional media was maintained throughout his government (Fenaj, 2019).

In March 2019, Bolsonaro started live weekly broadcasts via Facebook as a way to circumvent the traditional media and keep his support base mobilized. Adopting the same communication style that helped him win the election, Bolsonaro continued to use social media to publicize government actions, criticize his opponents and defend himself from attacks. These networks became the main source for government information, and the media had to refer to these networks to obtain said information as the government refused to talk to any media it believes to be producers of lies (Pereira, 2021). 
There were countless attacks made against the press by the president. In October 2019, TV Globo aired a report on the investigation into the murder of councilwoman Marielle Franco and her driver Anderson Gomes, on March 14, 2018 , in Rio de Janeiro. According to the report, case investigators heard testimony from a doorman at Bolsonaro's compound when the murder took place who revealed that Élcio de Queiroz, one of the suspects in the case, was at the compound on the day the murder took place, saying he had gone there to visit Bolsonaro. Soon after this report was released, Bolsonaro broadcast live via Facebook, criticizing Globo and claiming to be a victim of "shenanigans". "It's villainy what you guys are doing, TV Globo. It's villainy, to run a story like this on primetime TV, claiming that I could have participated in the murder of Marielle Franco". He even threatened not to renew Globo's concession in 2022 if the broadcaster has any fiscal irregularities: "This won't be good for you or anyone else" (Pereira, 2021).

On December 20 of the same year, Bolsonaro lashed out at a reporter who asked him about ongoing investigations into his son, Flávio Bolsonaro. "You have a terribly homosexual face, but that's no reason to accuse you of being a homosexual, even though it is not a crime to be a homosexual", the president said. In the same interview, Bolsonaro lashed out at another reporter who asked him whether he had proof of a suspicious deposit made by Fabrício Queiroz, a former adviser to Flávio Bolsonaro who was under investigation for corruption. "Damn it, boy, ask your mother if she gave your dad a receipt, okay? For God's sake. Voucher, they want proof of everything", he said.

In May 2020, Bolsonaro was irate when journalists asked him whether he had requested to change the superintendent of the Federal Police (PF) in Rio de Janeiro. "Shut up, I didn't ask you anything", he replied. Reporters insisted and he repeated: "Shut up, shut up" (BBC News, 2020).

The constant insults and threats by Jair Bolsonaro supporters, encouraged by the president himself, led media outlets to suspend their news coverage at the entrance to the Alvorada Palace on May 25, 2020. This decision was made by the Folha de S.Paulo newspaper, the Bandeirantes television network, the Metrópoles and UOL websites, and Globo Group media outlets, including TV Globo, Globo News, O Globo, and Valor Econômico newspapers, and the G1 portal in an attempt to protect the physical integrity of their reporters. 
Attacks have intensified in the context of the pandemic. As the virus spreads across the country, the president maintains his negationist position and continues campaigning against traditional media. Bolsonaro and his supporters use the discourse that journalism tries to "damage the government with lies". The news coverage of the pandemic is repeatedly targeted by the president. He says that "much of the media has exaggerated this event", he associates the front pages of newspapers with "a search for chaos", he also says that the people "were deceived" by governors and "much of the media" concerning the coronavirus (Amaral, 2020). As the months go by, this position of discrediting news coverage is similar to one that spreads terror, hysteria, chaos, and panic.

The president's words end up legitimizing more aggressive actions by militant groups, creating a climate of distrust in the population towards journalists, with some more irresponsible people turning to violence. The President's systematic attempt to discredit the press and his supporters' actions against the media and journalists are reflected in a survey ${ }^{5}$ conducted by the National Federation of Journalists (Fenaj), which indicates 2020 as the most violent year for Brazilian professionals since records of attacks on press freedom started in the 1990s.

There were 428 cases of violence; $105.77 \%$ more than the 208 cases recorded in 2019. Discrediting the press was the most frequent form of violence, as it was in the previous year: 152 cases, representing $35.51 \%$ of the total. President Jair Bolsonaro was the main perpetrator of these attacks. He was responsible for 175 cases ( $40.89 \%$ of the total): 145 generic and widespread attacks on media outlets and journalists, 26 cases of verbal harassment, one case of a direct threat to a journalist, one direct threat to TV Globo, and two attacks against Fenaj.

At the top of the list of those who attacked and harassed journalists and media companies the most is the president's own family. First on the list is his son, Eduardo Bolsonaro (PSL-SP), a federal deputy, with 208 attacks against journalists. Next is the president himself with 103 attacks, then Rio councilor Carlos Bolsonaro (Republicans political party-RJ) with 89 , and senator Flávio Bolsonaro (Republicans political party-RJ) with 69. Continuing down this list we have other people associated with the president, such as ministers Damares Alves (Women, Family and Human Rights), Ricardo Salles (Environment), and Onyx Lorenzoni (Citizenship), and Vice President Hamilton Mourão. 
Bolsonaro's discourse against the press is not just delivered in words but also by actions, discrediting media outlets whose journalism irritates him and distributing more funds to other channels. A UOL survey ${ }^{6}$ comparing advertising revenues from the SBT and Record television stations between the first quarters of 2018 and 2019 showed a growth of $511 \%$ and 659\%, respectively. In light of the clash between Bolsonaro and the press, we need to remember that the media plays a central role in terms of building political images (Manin, 1995) and it is important to understand the role this media plays in building contemporary populism.

\section{Populism}

It is undeniable that populism has become a defining element of political modernity, albeit almost always an undesirable one (Carneiro, 2009). Nevertheless, the difficulty in conceptualizing populism has been noted by several authors who describe just how complex it is to reach a definition that captures the phenomenon in different cultural and historical contexts (Rooduijn et al., 2014).

Despite this inaccurate definition, there is a relative consensus that populism, in the political spectrum, is a political style or strategy in which a charismatic and personalistic leader seeks popular support and bypasses political parties and projects linked to them (Carvalho, 2009). There is also a shared notion that populism is a set of ideas that describe society as a conflict between two rival poles (people vs. elite) (Mudde \& Kaltwasser, 2017; Rooduijn et al., 2014).

So, when this populism discourse is adopted by the left, it acts in favor of the poor people and fights against the wealthy, rightwing ruling elite; however, when adopted by the right, this discourse talks about the need to defend a silenced majority, which sometimes needs to be protected from external threats. It is important to highlight that populism is not limited to the definition of a single type of ideology restricted to a historical period. In other words, populism does not belong to one side of the political spectrum or another; different groups and ideologies adopt it to survive (Carvalho, 2009).

Roberts (2006) argues that populists present themselves in contexts of extreme inequality in environments of generalized dissatisfaction. In addition to these factors are crises in the political party systems brought on by their incapability to structure electoral 
demands and ultimately a lack of credibility among voters, which tends to push the public more towards electing populist leaders.

Mouffe (2000 as cited in Cesarino, 2020) also point to an opposition between populism and institutionalism: "moments of populist rise are usually accompanied by institutional fragility and, conversely, moments of technocratic preponderance stifle the antagonistic-populist character of politics" (Cesarino, 2020, p. 98). "Typically, the populist mechanism is put into operation by a charismatic leadership that emerges in contexts of widespread dissatisfaction, claiming to come from outside the system and placing itself as a champion of rupture and change" (Cesarino, 2020, p. 98). The discursive character is built from the mobilization of empty or floating signifiers, which, according to Cesarino, bring "vague notions of nation, order, security and change", but are capable of bringing together contrasting agendas.

In this way, populists gain supporters and visibility by claiming to be defenders of ruptures and changes. Laclau (2005) points out that the friend-enemy dichotomy in populism is replaced by the elite-people division, where the political leader starts to represent the interests of the majority against a corrupt and privileged elite. Populist leaders often emerge with the promise of giving a voice to those who have been neglected by the system and clashing with existing institutions such as traditional media or the judicial branch, ultimately driving them away or making them enemies of the people.

Mazzoleni (2008) consider that the constitution of contemporary populism is not only present in the type of politics or in the way leaders speak, but mainly in how the media system relates to the political field. Thus, according to these authors, the media has an important role in this phenomenon either because it directs it, or it is directed by it.

The authors understand that the media is the only factor responsible for what is known as neopopulism. The media's importance in this phenomenon is related to the fact that, from a news point of view, it cannot ignore an event that will attract the attention of viewers or readers (Mazzoleni, 2008). Political agents, such as Bolsonaro, who challenge the order and attack institutions obtain visibility in the media; on the other hand, populist leaders use that visibility as a communication strategy to gain newsworthiness. There is a mutual dependence here: the media needs stories, especially dramatic ones, and the populist movement depends on 
the visibility that the media can provide.

The media contributes greatly to creating a favorable field for populist discourse. By condemning politics and institutions and celebrating their failures, the media is contributing to a populist discourse that gains space. Along these lines, Vasconcellos (2013) points out that by providing negative and dramatic coverage of the situation the media is actually indirectly encouraging a feeling of insecurity throughout society, spreading a general sense of malaise and social tension that can trigger feelings of anti-establishment and pro-reform, and even shift political loyalties.

Having said that, Carneiro (2009) highlights some characteristics regarding the style of political communication that neo-populists adopt, which include (1) seeking a strong charismatic appeal with their voters through communicative efforts; (2) supporting an anti-political discourse; (3) presenting a polarizing discourse; (4) seeking support from specific clients; (5) using a vertical structure to gain power. Vasconcelos (2013) adds that these charismatic and strongly personalistic leaders can be identified by their visibility and controversial ideas. It also stands out for its political action almost always aimed at a central issue.

For example, Bolsonaro used the networks to establish a bond with voters that brought about a sense of esteem and charisma among supporters. He continued his polarizing us versus them discourse that labeled him as a political outsider and sought support from specific sections of the population such as the traditional Brazilian family. He also criticized traditional media, used alternative strategies to communicate, and won the election by focusing his discourse on public security. This simplicity in political action is easily spread among voters.

Mazzoleni (2008) also define the phases of neopopulism. The first phase, according to these authors, is characterized by a strong social and political discontent in the country. The second phase is the affirmation of neopopulism as a channel for meeting demands. Here, the role of the media becomes effective as it gives a visible platform to new political movements. The third phase tends to cause the movement to shrink, as leaders find it more difficult to hold media attention, which can adopt a hostile-to-friendly stance. The last phase is characterized by the reduced space that media gives to these parties and movements. At this point, media attention may shift due to the leader's declining popularity or even the emergence of a 
new neo-populist leader (Mazzoleni, 2008). In addition to discussing the role of traditional media in populism, it is important to bring up discussions about digital populism.

Cesarino (2020) uses the term digital populism supported by the conceptual basis of the people vs. the elite, as proposed by Laclau. This concept is used to describe a new type of strategy that uses digital mediums, which can mobilize networks of followers who form a support base for the leader's political project. As Prior explains (2019), suspicious of the hegemonic media, neo-populist leaders use direct communication strategies, most often supported by digital communication mechanisms, as a way to reach the people without the use of any intermediaries. These digital communication channels became a strategy that these movements use to spread populist rhetoric and political propaganda and thus leading to the rise of digital populism.

Therefore, digital populism, for this author (2019), is not defined only by the insertion of digital technologies into the populist dynamic, but also by the inclusion of specific discursive patterns that are structured in permanent mobilization. As Cesarino (2020) explains, this occurs through alarmist and conspiracy-based content by creating a direct and exclusive channel of communication between the leadership and its supporters that delegitimize institutions that produce authorized knowledge in the public sphere, specifically the academy and the press.

Prior (2019) states that digital media provides populist movements with alternative news channels to encourage and disseminate an anti-government discourse, hence maintaining the populist support base. In recent years, politics has found its way into social networks, an environment where the dissemination of false content, informational junk, rumors, conspiracy, and polarization is growing. Galito (2017) says that networks are unpredictable, uncontrollable, and conducive to populism, especially in a highly complex and competitive context in which serious issues are mixed in with entertainment. Thus, understanding how populism has adapted to networks is fundamental, especially at a time when the pandemic and discrediting institutions are so prevalent. 


\section{Methodological procedures}

The arrival of internet access on a global scale and personal devices has reshaped social relations, ways of learning, the production, consumption, and circulation of news and cultural objects, as well as the public sphere itself. This new role of communication, which was previously assigned to traditional media and large companies, now gives a voice to anyone who owns a personal device and has access to the internet. Traditional journalism has lost space to the rapid dynamics of social networks and alternative media. Another challenge is the feeling of distrust that many citizens have about information produced by the hegemonic media.

For Gerbaudo (2018), this disbelief that individuals hold concerning the traditional means of communication has provided an adequate channel for populist rhetoric to manifest, as well as for citizens to express their indignation about the elites they consider to be corrupt, which includes the press. In this sense, social networks are tools for growing anti-establishment mass politics. This author coined the term populism 2.0 to describe an ideological direction where politicians capitalize on the power and influence of social media and use it to shape citizen opinion through the dissemination of populist ideas, such as attacking institutions.

Given the context explained by the theoretical review of populism, we propose to identify how the Bolsonaro support network incorporated the rhetoric of the "people" vs. "elite" populism, where the elite is the press, seen as an enemy of the leader. This paper seeks to assess how a network of conversations was built around criticisms that President Bolsonaro delivered to the press in the week of March 3 to 8,2021 , when Brazil reached the highest average number of covidrelated deaths since the onset of the pandemic.

We chose Twitter because it is one of the main networks used in Brazil, a country that has the fifth largest population of social media users worldwide (Statista, 2021). In this paper, the network consists of actors (referred to as nodes) and connections (referred to as quotes, mentions, or retweets), and the metrics used for measuring modularity and degree of connection are parameters to identify the main clusters and the 15 agents with the greatest influence. The data used for this study was collected from the Netlytic software on days 3, 5, and 8 of March 2021 , with a total of 2.500 daily mentions. Data was collected by the script <"Press" AND "Bolsonaro" AND "Covid" 
OR "Coronavirus">. The Gephi software was used for analyzing and visualizing network data.

\section{Network analysis}

This research is based on the Social Network Analysis (SNA) which, according to Recuero et al. (2016), makes it possible to study the connections, actions, and interactions between actors in a given network. This analysis is associated with digital ethnography, which considers cultural and conjunctural elements. Each graph contains mentions and retweets. Graphs are visual representations of the models and metrics of a network, in other words, the set of interrelationships between its elements. The relationships between nodes (social actors represented by their nicknames or the @ symbol) and edges (connections) are observed in these elements.

It is possible to establish weight and strength relationships for nodes and clusters (defined as a dense aggregate of nodes) formed in their connections, and the greater the number of interactions between two or more accounts, the greater the weight of these connections. Each graph can have one or more clusters, which can be more or less dense (Recuero et al., 2018).

About the metric of nodes, the graphs can be more or less centered, according to the degree of the node and other factors. The more connections a node has, the more central it will be to the network. This degree can be measured by the number of connections a node receives (degree of input or, indegree) or by the number of connections made by a node (degree of output or, outdegree) (Recuero et al., 2018). In this article, we analyze the degree of entry of nodes and the composition of clusters through mentions and retweets. The Force Atlas 2 parameter, available in Gelphi, is based on force relationships and was used to represent these relationships.

The network of the respective days consisted of 2.452 nodes and 7.226 edges. The modularity of the network is 0.453 . The network figure (Figure 1) shows a strong polarization between the clusters of supporters and the critics of Bolsonaro's discourse despite the supposed narrative that the press harasses the president by exaggerating the level of the covid-19 crisis in Brazil. 
Figure 1 - Conversation network about Bolsonaro's criticisms of the press

The blue and light/dark green group mainly aggregates (figure 2) supporters of the president who propagate criticisms of the press.

Figure 2 - Clusters of press criticisms that stood out the most 
The opposition clusters to Bolsonaro (figure 3) are arranged in the following colors: the red cluster collects the accounts that refute Bolsonaro's discourse, with a large number of these profiles being from the press and/or linked to the media groups. The pink cluster represents Internet user profiles that criticize the government, and the orange cluster represents the journalists' accounts. The yellow cluster represents a politician's account.

Figure 3 - Clusters of opposition to Bolsonaro narratives that stood out the most

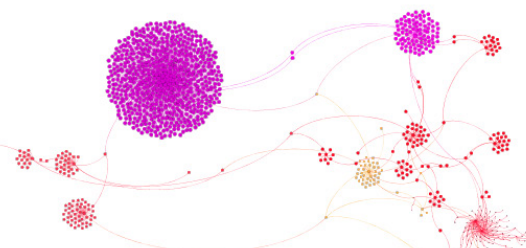

In the clusters that we refer to as Bolsonaro supporters, retweets were circulated with messages criticizing the manipulation of the press and listing the challenges that Bolsonaro faces in governing the country. Table 1 lists the relative position of activists ${ }^{7}$, indicating a greater level of indegree connection (sum of RTs and mentions each profile received) and the position of each cluster in the network. Despite forming distinct clusters, we decided to use the same color for modules that mentioned (retweets) the same content.

Table 1 - Classification of nodes with greater indegree in clusters

\begin{tabular}{|l|l|l|l|}
\hline Node & Indegree & Module & Color \\
\hline Activist 1 - conservative profile & 166 & 42 & Light green \\
\hline Activist 2 - conservative profile & 153 & 168 & Light green \\
\hline Activist 3 - patriot, right-wing affiliation & 94 & 92 & Light green \\
\hline Activist 4 - professor, right-wing affiliation & 67 & 91 & Light green \\
\hline
\end{tabular}

Activists with a conservative profile mentioned the fact that the press manipulated data related to the drop in the Gross Domestic Product (GDP), a decline that was shown to occur in numerous 
countries impacted by the Covid-19 crisis. When reporting the drop in GDP in Brazil, according to Bolsonaro supporters, the media claimed the president was solely responsible for this decrease and did not name any other possible factors.

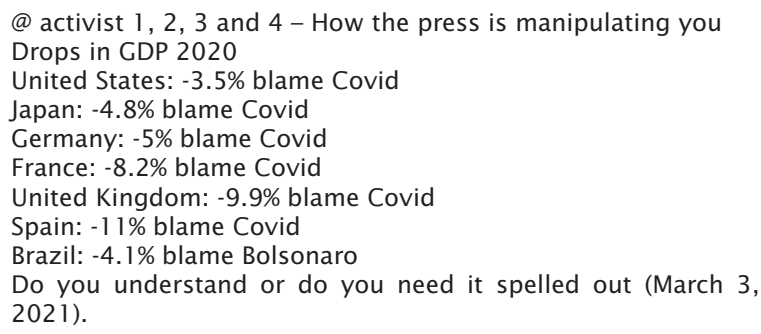

Table 2 shows the position held by profile @coronelsandromg, the State Deputy of Governador Valadares, in the cluster.

Table 2 - Classification of indegree for Colonel Sandro in the cluster

\begin{tabular}{|l|l|l|l|}
\hline Node & Indegree & Module & Color \\
\hline Coronelsandromg & 69 & 174 & Dark blue \\
\hline
\end{tabular}

The state deputy describes himself as being a christian, a patriot, and a conservative, and says that Bolsonaro, like other world leaders, is not only fighting against covid-19 but also against different institutions that oppose him, including the press.

\footnotetext{
@coronelsandromg - Leaders around the world are fighting Covid-19 in their countries, except in Brazil. Here, Bolsonaro fights against Covid, against the press, against corrupt governors and mayors, against leftists, against saboteurs, against activism (March 5, 2021).
}

Another activist claiming to be a conservative and a patriot also mentioned the harassment that Bolsonaro endures from most of the institutions in Brazil. Table 3 shows the position of this profile who we shall call Activist 4.

Table 3 - Classification of Activist 4 node in the cluster

\begin{tabular}{|l|l|l|l|}
\hline Node & Indegree & Module & Color \\
\hline Activist 4 - conservative and patriot profile & 153 & 168 & Dark green \\
\hline
\end{tabular}


The following excerpt comes from Activist 4 who received high indegree from supporters of the Brazilian president:

\begin{abstract}
@Ativitas 4 - Today, the challenge for the vast majority of countries is only the fight against Covid-19. The reality of President Bolsonaro is much more complex; he has to fight Covid-19, fight the press, fight traitors, the STF, and the corrupt system. His government is a victim of press harassment (March 4, 2021).
\end{abstract}

The profile of Activist 5 stands out in the graph. This activist received the greatest indegree throughout the analysis period, as shown in table 4.

Table 4 - Classification of Activist 5 node in the cluster

\begin{tabular}{|l|l|l|l|}
\hline Node & Indegree & Module & Color \\
\hline Activist 5 - Right-wing & 166 & 164 & Light blue \\
\hline
\end{tabular}

This right-wing activist suggests that in order to end the Covid-1 9 crisis, Bolsonaro would have to buy the country's corrupt press.

@ativista 6 - If Bolsonaro wants to put an end to Covid-19, it's simple.

JUST BUY THE PRESS.

Corrupt press (March 5, 2021).

Table 5 lists the relative position of the press, indicating a greater degree of indegree connection (sum of RTs and mentions that each profile received) and the position of each cluster.

Table 5 - Classification of newspapers and journalists with greater indegree in clusters

\begin{tabular}{|l|l|l|l|}
\hline Node & Indegree & Module & Color \\
\hline Uol & 60 & 13 & red \\
\hline uol notícias & 66 & 13 & red \\
\hline dcm_online & 34 & 140 & red \\
\hline brasil247 & 21 & 140 & red \\
\hline Folha & 30 & 124 & red \\
\hline Bbcbrasil & 47 & 109 & red \\
\hline Jornalista 1 & 78 & 181 & orange \\
\hline Jornalista 2 & 20 & 124 & orange \\
\hline
\end{tabular}


The red clusters represent the online newspapers, and the orange cluster represents two journalists. These media outlets echoed the news reports on Bolsonaro's discourse in relation to the increased death toll in the first week of March and highlighted the president's criticisms of the press.

@folha - Faced with a record number of Covid-related deaths, the lack of hospital beds, and the low rate at which people are being vaccinated in Brazil, Jair Bolsonaro turned his criticisms to the press. "For the media, the virus is me", he told supporters in the Alvorada Palace garden (March 3, 2021 ).

$@ b b c b r a s i l$ - "Enough of the complaining and hypersensitivity. For how long are they gonna complain?", Bolsonaro said on Thursday (4) - he reiterated that he is regretting the deaths by covid-19, but said that the economy needs to continue to move forward, and criticize the press and quarantines (March 4, 2021).

@dcm-online / @brasil 247 - Bolsonaro said that the press created 'panic over Covid' after more than 1,700 people died in a single day (March 3, 2021).

Journalists belonging to the press cluster commented on Bolsonaro's discourse about the lack of control over the pandemic in the country, indicating the president's failure to develop a strategy and that he prefers to blame the press for the crisis.

Journalist 1 - Another record for Brazil. 71,704 confirmed cases of COVID-19 in one day. 1,910 deaths in just 24 hours, which equates to 1 death every 45 seconds. Meanwhile, Bolsonaro says that everything is fine, that the press exaggerates, and that Brazil is exemplary. What a tragedy! (March 4, 2021).

Journalist 2 - The press creates panic over covid, says Bolsonaro while deaths rise $11 \%$ (March 7, 2021).

Table 6 shows the position of activists and Senator Cid Gomes, indicating the level of indegree connection and the position in the clusters.

Table 6 - Classification of nodes with greater indegree in clusters

\begin{tabular}{|l|l|l|l|}
\hline Node & Indegree & Module & Color \\
\hline Activist 1 & 624 & 187 & Pink \\
\hline Activist 2 & 66 & 167 & Pink \\
\hline Senator Cid Comes & 34 & 154 & Yellow \\
\hline
\end{tabular}


Activist 1 obtained a greater degree of entry into the network during the period. He recalled the time when Bolsonaro tried to humiliate the press by having a comedian hand out "Italian salutes" to journalists covering the first covid-19 cases in Brazil. Activist 2 criticized the politics and economics of Bolsonaro and the ministers of health and economy, emphasizing the neoliberal posture of the press in the country. Politician Cid Gomes warned that Bolsonaro is a coward for blaming the press for the pandemic crisis at a time when the country faced the highest death rate.

\begin{abstract}
@ativista 1 - Two days from now, this scene will be a year old. A clown dressed as Bolsonaro handed out "Italian salutes" to the press. This clown came out in place of the president and answered questions about the GDP, which had registered a mediocre growth of $1.1 \%$ in 2019. There were four confirmed cases of Covid-19 in Brazil at the time (March 4, 2021).

@ativista 2 - The new lethal strain of the Coronavirus in Brazil is the result of a combination between neoliberalism, expenditure caps, Paulo Guedes, a pre-paid press that defends private banks, Bolsonaro, and the corrupt general Pazuello in the Ministry of Health (March 8, 2021).

@senadorcidgomes - Bolsonaro's cowardly crusade continues at a high pace. The country has just lost 1,910 of its children. And what does this unfit leader do? Blame the press. Brazil has had an $11 \%$ increase in deaths. In the world, there is a $6 \%$ decrease, according to the WHO. It's perverse (March 5, 2021).
\end{abstract}

In order to identify traces of populism in the mentions of the polarization of the press vs. Bolsonaro, a detailed analysis of the 15 main retweets supporting the president on the network will be carried out.

\title{
6 Content analysis
}

Content analysis was the chosen methodology for analyzing the content of the network because it is a method with great adherence to online discourse studies (Lindgren and Lundstrom, 2011). Among the various forms of analysis, Bardin (2011) points out that content analysis allows for a quantitative and qualitative approach to studying digital space. The analysis consists of three steps: data coding, categorization, and inferences.

For the coding and categorization phases, the survey included the 15 tweets that received the highest level of entry in Bolsonaro's support network. The content was submitted to the Automated Content Analysis method (Cervi, 2018), supported by the Iramuteq 
software which comprises an $\mathrm{R}$ data processing package to build a dendrogram that accounted for the semantic recurrence of the text.

To understand the occurrence of words, the text corpus was classified by Reinert's (1990) algorithm, also known as Descending Hierarchical Classification (DHC). Reinert's method produces clusters based on the proximity between terms. Cervi (2018) explains that Reinert's algorithm was inspired by Benzécri's (1992) proposals for lexical analysis and involves presenting the word distribution laws in any textual corpus. Incorporated by the R statistical package interface for textual analysis, Iramuteq absorbed the DHC analysis algorithm and maintained the name of the author of the theory.

The method, as Cervi explains, is effective because it removes subjectivity from the content analysis by predicting the least possible interference by the researcher in textual categorization. Reinert's algorithm proposal reverses the process as "an output is sought, in the empirical corpus itself, through the use of Reinert's algorithm, the identification of the terms that most appear and that come close to each other in the texts and, therefore, form classes of terms with internal homogeneity" (Cervi, 2018, p. 8).

Based on this information our automated analysis was conducted to identify the number of clusters for the total set of 15 retweets that represented criticisms of the press. Dendrogram 1 (figure 4) shows the four categories.

Figure 4 - Dendrogram 1 - numbers of classes for all texts

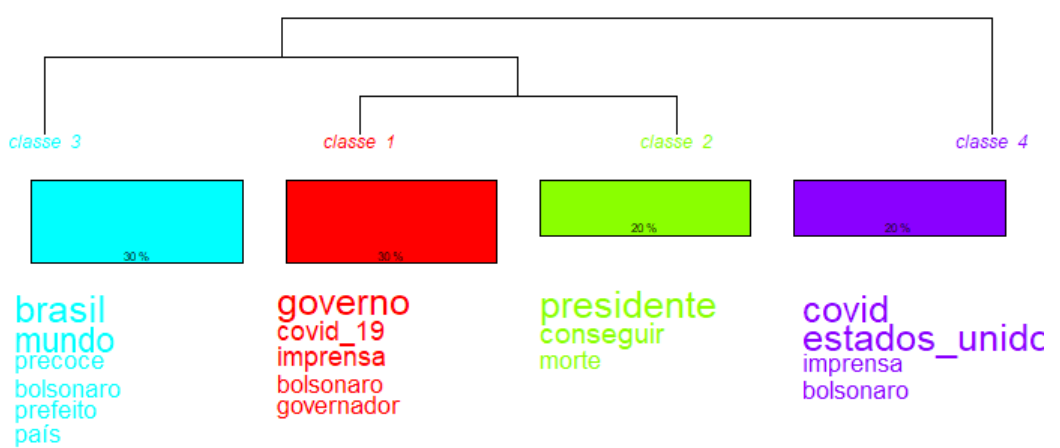

The participation percentage for each class in all the texts shows classes 1 and 3 to have the largest percentage with $30 \%$ of the valid terms, followed by classes 2 and 4 with 20\%. Class 3 presents a higher frequency of the words Brazil, world, premature, Bolsonaro, 
mayor, disinformation, enemy, blame, etc., and evokes terms that are associated with the alleged manipulation built by the press to damage the president's image and his handling of the pandemic. Similarly, class 1 shows terms linked to the press' harassment of the government (particularly on issues regarding the pandemic) in contrast to the support it establishes for corrupt politicians, such as governors from different regions of the country. The words used the most in this cluster were government, covid-19, press, Bolsonaro, governor, destroy, and harass.

Class 2 mentions the terms president, obtain, death, corrupt, responsibility, etc., and portrays the difficulties Bolsonaro faces in fighting a corrupt press that blames him for the covid-related deaths in the country. On the other hand, class 4 contains words indicating that the left-leaning press boycotts Bolsonaro to remove him from power, using terms such as covid-19, United States, press, Bolsonaro, left, coup, and boycotting as the most frequent.

It is worth noting that the Reinert method indicates the classes and words that appear the most in a given cluster, showing which terms are specific to each group based on Pearson's $\chi 2$ test, a method that measures whether the presence of a term in a cluster is statistically different from the presence of the same term in other clusters (Cervi, 2018). Thus, the construction of analytical categories built by Reinert was classified according to table 1, in which Pearson's $\chi 2$ test, the number of occurrences of the terms, and the naming of each category were considered. The names of the categories were defined by the authors based on the analysis of the set of terms represented in each class.

Table 7 - Naming of categories by the term

\begin{tabular}{|c|c|c|c|c|}
\hline & Class 1 & Class 2 & Class 3 & Class 4 \\
\hline $\begin{array}{l}\text { Terms with } \\
\text { Pearson's } \\
\chi 2 \\
\text { (important } \\
\text { terms by } \\
\text { class) }\end{array}$ & $\begin{array}{l}\text { Covid-19, } \\
\text { press, } \\
\text { Bolsonaro, } \\
\text { governor, } \\
\text { destroy, } \\
\text { harass, bad. }\end{array}$ & $\begin{array}{l}\text { President, } \\
\text { obtain, death, } \\
\text { corrupt, } \\
\text { responsibility, } \\
\text { system, buy. }\end{array}$ & $\begin{array}{l}\text { Brazil, world, } \\
\text { premature, } \\
\text { Bolsonaro, } \\
\text { mayor, } \\
\text { disinformation, } \\
\text { enemy, blame, } \\
\text { manipulate, } \\
\text { fantasy. }\end{array}$ & $\begin{array}{l}\text { Covid-19, } \\
\text { United } \\
\text { States, } \\
\text { press, } \\
\text { Bolsonaro, } \\
\text { left, coup, } \\
\text { radical, } \\
\text { ideological. }\end{array}$ \\
\hline $\begin{array}{l}\% \text { of } \\
\text { frequency }\end{array}$ & $30 \%$ & $20 \%$ & $30 \%$ & $20 \%$ \\
\hline $\begin{array}{l}\text { Name } \\
\text { given to } \\
\text { category }\end{array}$ & $\begin{array}{l}\text { Press } \\
\text { harassment }\end{array}$ & Corrupt press & $\begin{array}{l}\text { Manipulative } \\
\text { press }\end{array}$ & $\begin{array}{l}\text { Left-leaning } \\
\text { press }\end{array}$ \\
\hline
\end{tabular}


In order to understand the results, the content of the tweets was examined from the perspective of populism, based on the thematic classification defined in the previous phases.

The "corrupt press" category includes tweets that support the populist leader's battle against corrupt institutions, notably the press. The tweet "If Bolsonaro wants to put an end to Covid-19, it's simple. Just buy the press. Corrupt Press" reproduces the key concept of populism that divides society into two antagonistic groups, suggesting that the media's agenda functions according to "financial agreements", in counterpoint to the extraordinary leader who articulates a myriad of popular dissatisfactions, which are the result of a corrupt establishment (Mudde \& Kaltwasser, 2017).

The global democratic crisis translates into an epistemological crisis that results in disbelief in traditional institutions and has led citizens to express their indignation towards political elites they view as corrupt and toward the hegemonic media itself which, as pointed out by Albuquerque and Quinan (2019), is seen as a member of the financial establishment and thus also seen as corrupt. In a crisis scenario, Mede and Schäfer (2020) reiterate that populists are not only targeting political elites; they are also targeting other institutions such as traditional media, the legal field, large companies, scholars, academic experts, and specialists. The populist discourse, which is repeated in the Bolsonaro supporters' network, is linked to the idea that Cesarino (2020) borrowed from Laclau when he pointed out that the leader represents "the common people" who fight against some kind of privileged, self-interested, hypocritical and/or corrupt elite.

Drawing on the position of the National Federation of Journalists, which monitors attacks and violence suffered by the press (particularly regarding Bolsonaro), National Federation of Journalists (Fenaj) claims that these media attacks that reverberate on the networks "are a way for the president to encourage his followers to not trust the journalistic work of most vehicles and professionals, especially when that work criticizes the government or involves the Bolsonaro family and is broadcast" (Fenaj, 2019). This act is based on the formula that anyone who does not think or act following the populist leader is a country's enemy (the country personified in the personality of the president). One of the impacts of this type of communication is that it sustains the Manichean view of opposite poles in narratives that support the leader.

The narrative expressed by Bolsonaro supporters uses the premise that there are two distinct groups in society: the people and the 
corrupt elite; in addition to the idea that the president represents the will of the "people" as opposed to "the whole system". There is a constant notion of crisis in this discourse, one in which Bolsonaro assumes the leading role and is the only one capable of fighting everyone. The tweet "Today, the challenge for the vast majority of countries is only the fight against covid-19. The reality of President Bolsonaro is much more complex; he has to fight covid-19, fight the press, fight traitors, the STF and the corrupt system" falls into the same category and repeats this practice by claiming that the press and institutions act in opposition to the president and are adding to the country's crisis. The "us" against "them" discourse is evident here, the latter in this case describing the corrupt and traitors who oppose the leader and fit the anti-system profile, whose mission is to fight against the corrupted status quo.

The tweets looking to connect the actions of the press with the political left make up the "leftist press" category. To analyze this category, it is important to reiterate that Bolsonaro's entire 2018 election campaign was built on this idea of him being an outsider politician, one who is opposed to corruption, to communists, and the leftist PT party. At the time, the left-wing Workers Party (PT) was still suffering the effects of the Car Wash scandal and was accused of participating in corruption during their time in power. At a time when supporters of the Workers Party were equated to being immoral or negative (Maitino, 2020), Bolsonaro built a discourse that united being a good citizen with being right-wing. Bolsonaro's populist rhetoric during his electoral campaign, his anti-establishment discourse, criticized the Workers Party, left-wing supporters, and communism.

The tweet "The extreme press got what it wanted by removing Trump. Now they are trying to make Brazil seem like the worst country in the world in terms of daily Covid-related deaths in an attempt to remove Bolsonaro, an enemy of militant journalism", is an example of the binary rhetoric of "right" against "left" being spread across social networks. The discourse that Bolsonaro supporters present is based on the same conspiracy theory that surrounded former president Donald Trump's defeat in the 2020 American elections. The allegation that American institutions devised a plot to boycott Trump's victory in 2020 was something Bolsonaro came to the defense of, up until Democrat Joe Biden was elected. In the text, this same logic of conspiracy is transferred over to the Brazilian scenario where the militant press takes on the role of enemy of the people.

The tweet "This is the height of antagonistic journalism. This is the extreme leftist press, this is the press that criticizes and spreads 
disinformation on a daily basis about Bolsonaro, Brazil, Covid-19", claims that the left-wing press is guilty of promoting a news agenda that misinforms and mocks the president. Mazzoleni (2008) reiterate that populist discourse can label the media as either an enemy or a friend, as long as that media supports their candidacy or party. In this case, the idea of populism portrays the press and the political left as the corrupt elite because they release news about the devastating effects of the pandemic with the sole purpose of damaging the image of the country and of the president.

The idea behind absolving the Federal Government from any blame over the health crisis and accusing the rival group of purposely creating a scenario of terror is verified in the tweet "The country can no longer withstand this Covid-19 terrorism supported by the left and the press". Guided by populist rhetoric, the network of Bolsonaro supporters sees the press as a threat because the president's discourse, that said media reports on and broadcasts, receive negative repercussions in most national and international newspapers. Similar to how the president's discourse sought to create a distrust of Brazilian journalism, the Bolsonaro support network attacks the press as if they were not in favor of democracy, mainly criticizing the credibility of the journalistic work, claiming the media has a hidden agenda with communist and corrupt governments.

The category "manipulative press" addresses how the press hides and distorts information in order to damage Bolsonaro's image. The tweet that addresses the press' manipulation of the drop in the GDP in Brazil claims that the media attributed the drop in GDP in different countries to the Covid-19 pandemic. In Brazil, however, it takes on a different tone: "Brazil has a GDP of $-4.1 \%$ and Bolsonaro is to blame. Is that clear or do you need it spelled out?" The tweets "Bolsonaro quoted as saying Israel should seek a deal to get nasal spray against Covid" and "Does Monalisa Perrone seem more upbeat when she reports on issues other than the Covid-19 tragedy? She, and our press, are rooting for the virus to get worse" follow the same line of accusing the newspapers of adopting an editorial line that is in opposition to the government.

Several statements taken from Twitter fall in line with Bolsonaro's populist rhetoric of being a well-intentioned political figure who fights against the attacks of the nation's enemies, mainly specialists and researchers, the press, corrupt politicians, mayors and governors of countless regions, and anyone else who does not support Bolsonaro's actions. The logic that there is nothing wrong with the government 
and it is the press that is distorting the facts is repeated throughout Bolsonaro support networks. In the text, journalist Monalisa Perrone is seen as being responsible for the problems she reports on and accused of conspiring against the current government. The press is also accused of building a news agenda to silence Bolsonaro's steps and policies and instead highlight the achievements of São Paulo governor João Doria (PSDB). The populist discourse, in this case, is established by returning accusations (Cesarino, 2020), by blaming the press for building up a supposed health crisis, one that is caused by broadcasting headlines that blame Bolsonaro for the impacts of the pandemic.

Lastly, the press category "press harassment" contains tweets that describe the media siege of blaming Bolsonaro for the pandemic. In the mention "Government is a victim of press harassment. Leaders around the world are fighting covid-19 in their countries, except in Brazil. Here, Bolsonaro fights against covid-19, against the press, against corrupt governors and mayors, against leftists, against saboteurs, against activism", the support network for Bolsonaro once again incorporates a binary populism of the sincere and well-intentioned leader who fights against several conspiracies and enemies.

The binary narrative of the elite and the people (Laclau, 2005) and the discourse centered on the figure of a personalist leader (Waisbord, 2013; Mudde \& Kaltwasser, 2017) encapsulate the common distinctive features of populist rhetoric of harassment, expressed in the tweet that says the Supreme Court judges, governors and mayors are the ones who are truly responsible for the pandemic crisis. The press is made out to be the enemy of Bolsonaro, focused on destroying his image and encouraging the quarantine policy. The phenomenon of populism presupposes an environment of mistrust and confusion where the producers of these types of content wish to create a disbelief in the press and politicians, basically reproducing the leader's logic. By opposing institutions, Bolsonaro is mobilizing agendas that his supporters can easily follow and share.

Traces of angry populism in the Bolsonaro support network, described by Wahl-Jorgensen (2018 as cited in Viscardi, 2020), must be considered as a rhetoric that intentionally employs anger as a tactic. Viscardi (2020) describes the populist discursive strategy behind angry populism as one that is used by those who feel they identify with the leader. The formation of the "people" and "leader" poles are structured in an antagonistic way and the formation of the "people" category occurs from the creation of a global identity derived from the "equivalence of 
a plurality of social demands" (Laclau, 2005, p. 83). For Viscardi (2020), training in the constitution of the unit could reflect the "demonization of a part of the population or a common demand" (p. 1139).

The logic of angry populism can be seen in the following mentions: "Our mental state is terrible, but we will always support Bolsonaro. We know they want to defeat the President, we are not idiots" and "Bolsonaro fights against Covid-19, against the press, against corrupt governors and mayors, against saboteurs, against activism". The narrative employed by Bolsonaro supporters seeks to discredit the image of newspapers and journalists. It distills hatred, a strategy that plays on the emotional side of populism, expressed through hostility against the institutions that anger the president.

\section{Final considerations}

This hate directed toward the press is part of a worldwide movement on the far right which, by appropriating social media, has given rise to the phenomenon of digital populism. In this context, any news in opposition to the populist leader is subsequently used by that leader's followers to attack the "ones who question", emulating the classic element of "friend" vs. "enemy" populism.

Understanding digital populism is fundamental in light of the discussion about Bolsonaro support networks. Bolsonaro has always used social media as a communication tool with his electorates, mainly because digital platforms and networks are able to maintain the antisystem and negationist narratives in the midst of the pandemic. In this way, as research has shown, Bolsonaro support networks had to attack opponents and institutions, while ignoring scientific recommendations. The Bolsonaro support network we analyzed is completely opposed to the traditional press and its intermediary position of communicating the science behind covid-19 with the public. What's more, these strategies act as a direct channel between Bolsonaro and his followers, maintaining a share of $20 \%$ to $25 \%$ of the electorate despite the decline in his popularity due to the problems arising from the serious health, economic and social crisis in the country.

Our analysis also required us to identify the strategy behind how Bolsonaro and his allies use the tweets to camouflage and deviate from the main problems and failures of the government. For example, by attacking the press, the president is trying to shift the 
focus away from the seriousness of the covid-19 health crisis, which accounted for approximately four thousand deaths per day. The press and scientific institutions present themselves as an obstacle because they shed light on both the pandemic and on Bolsonaro's failures and mistakes, who have counted on herd mentality and treatments that are not proven to be safe or effective.

Bolsonaro also wants to hide the serious economic and social problems that have not been resolved and have intensified during his administration. Furthermore, Bolsonaro and his allies are targets of corruption allegations that call into question the anti-corruption discourse of the 2018 campaign. Faced with failures such as making the public funding work and putting into practice the policies the president had promised to his electorate, particularly opening up the market, the Bolsonaro support networks go on the offensive against those institutions that criticize the government the most, trying to make them out as scapegoats. The press, political institutions, the communist left, and everything else that represents an obstacle to Bolsonaro's antisystem policy must be blamed. But it's all just empty populist rhetoric since, in practice, the responsibility for not having managed to implement the economic and political measures rests with the government itself. In the case of the pandemic, it has reached such levels of severity due to the president's decision to deny and play it down.

However, it must be stressed that authoritarian tendencies and attacks on institutions, including the press, are also harmful to democracy. A permanent state of crisis can have serious consequences in limiting perspectives on democratic regimes where the strengthening of authoritarian governments is shaped, which has been one of the hallmarks of populism throughout history.

\section{NOTES}

1 Businessmen finance campaign against PT through WhatsApp. Retrieved from wwwl.folha.uol.com.br/poder/2018/10/empre sarios-bancam-campanha-contra-o-pt-pelo-whatsapp.shtml

2 Folha is the biggest fake news in Brazil, Bolsonaro tells protesters. Retrieved from wwwl.folha.uol.com.br/poder/2018/10/folha-ea-maior-fake-news-do-brasil-diz-bolsonaro-a-manifestantes.shtml

3 On social media, Bolsonaro makes his first speech as elected 
president. Retrieved from www.correiobraziliense.com.br/app/ noticia/politica/2018/10/28/interna_politica,715932/nas-redessociais-bolsonaro-faz-primeiro-discurso-presidente-eleito.shtml.

4 At least 330.000 people followed the live stream. An hour later, the video had already totaled two million reproductions and more than 350.000 comments.

5 FENAJ 2020 Report - Violence against journalists and press freedom in Brazil. Retrieved from https://fenaj.org.br/wpcontent/uploads/2021/01/relatorio_fenaj_2020.pdf

6 Government pay for advertising up 63\%; Record surpasses Globo. Retrieved from https://noticias.uol.com.br/politica/ultimas-notici as/2019/04/15/gastos-publicidade-governo-bolsonaro-crescem-r755-mi-record-lidera.htm Last accessed on March 7, 2021.

7 The researchers chose to keep the profile of activists confidential, unless they are associated with public figures.

\section{| REFERENCES}

Albuquerque, A., \& Quinan, R. (2019). Crise epistemológica e teorias da conspiração: o discurso anti-ciência do canal "Professor Terra Plana”. Mídia e Cotidiano, 13(3), 83-104. DOI: 10.22409/rmc. v13i3.38088

Amaral, M. (2020). Montagens doentes e perversas: a informação no governo Bolsonaro durante a pandemia do coronavírus. Mediaciones Sociales, v.19, 1-6. DOI: 10.5209/meso.70289

Avritzer, L. (2020). Política e Antipolítica: a Crise do Governo Bolsonaro. São Paulo: Todavia.

Bardin, L. (2011). Análise de conteúdo. Lisboa: Edições 70.

BBC News (2020, 5 de maio). 9 ataques de Bolsonaro a jornalistas - e quais os temas que levaram presidente a perder a linha. Retrieved from https://www.bbc.com/portuguese/brasil-52553647

Benzécri, J. P. (1992). Correspondence Analysis Handbook. Nova lorque: Dekker.

Carneiro, G. O. (2009). A Nova Maioria: Determinantes do Apoio Político ao Neopopulismo na América Latina [doctoral dissertation, Universidade de São Paulo]. Biblioteca Digital USP. 
Cervi, E.U. (2018). Análise de conteúdo automatizada para conversações em redes sociais: uma proposta metodológica. Proceedings of the $42^{\circ}$ Encontro Anual da ANPOCS. Caxambu: ANPOCS. Retrieved from www. anpocs.com/index.php/papers-40-encontro-3/gt-31/gt17-22/1 1253analise-de-conteudo-automatizada-para-conversacoes-em-redessociais-online-uma-proposta-metodologica/file

Cesarino, L. (2020). Como vencer uma eleição sem sair de casa: a ascensão do populismo digital no Brasil. Internet \& Sociedade, 1(1), 91-120. Retrieved from https://revista.internetlab.org.br/serifcomo-vencer-umaeleicao-sem-sair-de-casa-serif-a-ascensao-do-populismo-digital-no-brasil/

Fenaj. (2019, January, 12). Violência contra jornalistas e liberdade de imprensa no Brasil. Relatório 2019. Retrieved from https://fenaj.org. br/wp-content/uploads/2020/01/relatorio_fenaj_2019.pdf

Galito, M. S. (2017). Populismo: conceptualização do fenómeno. Instituto Superior de Economia e Gestão. Working Paper CESA CSG, 158, 1-32. Retrieved from http://hdl.handle.net/10400.5/14156

Gerbaudo, P. (2018). Social media and Populism: An Elective Affinity? Media, Culture \& Society, 40(5), 745-753. DOI: $10.1177 / 0163443718772192$

Laclau, E. (2005). O Retorno do "Povo": Razão Populista, Antagonismo e Identidades. Revista de Ciências Sociais, (23), 9-34. Retrieved from https://periodicos.ufpb.br/ojs/index.php/politicaetrabalho/article/ view/6583

Lindgren, S., \& Lundström, R. (2011). Pirate Culture and Hacktivist Mobilization: The Cultural and Social Protocols of \#WikiLeaks on Twitter. New Media and Society, 13(6), 999-1018. DOI: $10.1177 / 1461444811414833$

Maitino, M. E. (2020). Populismo e bolsonarismo. Cadernos Cemarx, (13), 1-20. DOI: h10.20396/cemarx.v13i00.13167

MANIN, B. (1995). Metamorfoses do governo representativo. Revista Brasileira de Ciências Sociais, 29, 5-34. Retrieved from http://anpocs. com/images/stories/RBCS/rbcs29_01.pdf

Mazzoleni, G. (2008). Populism and the Media. In D. Albertazzi \& D. Mcdonnell, D. (Eds.), Twenty-First Century Populism: the Spectre of Western European Democracy (pp. 49-64). Basingstoke and New York, NY: Palgrave Macmillan.

Mede, N.G., \& Schäfer, M. S. (2020). Science-related populism: Conceptualizing populist demands toward science. Public Understanding of Science, 29(5), 473-491. DOI: $10.1177 / 0963662520924259$

Mouffe, C. (2000). The Democratic Paradox. Londres: Verso. 
Mudde, C. (1996). The War of Words Defining the Extreme Right Party Family. West European Politics, 19(2), 225-248. DOI: $10.1080 / 01402389608425132$

Mudde C., \& Kaltwasser, C. R. (2017). Populism. A Very Short Introduction. Oxford: Oxford University Press.

Pereira, M. R. (2021). A desinformação como estratégia política: uma análise dos tweets de ataque à imprensa postados por Jair Messias Bolsonaro no ano de 2019. Aquila, 1(24), 97-110. DOI: 10.17648/ revista-aquila.v1i24.149

Prior, H. (2019). Em nome do povo: o populismo e o novo ecossistema mediatico. Coimbra: Imprensa da Universidade de Coimbra.

Recuero, R., Bittencourt, M. C. A., Zago, G. da S. (2016). O discurso de veículos jornalísticos e a repercussão da audiência no Twitter sobre os protestos de 15 de março de 2015 no Brasil. Intercom, 39(3), 15 134. DOI: $10.1590 / 1809-5844201637$

Recuero, R., Bastos, M., Zago, G. (2018). Análise de redes para mídia social. Porto Alegre: Sulina, 2018.

Reinert, M. (1990). Alceste, une méthodologie d'analyse des données textuelles et une application: Aurélia de G. de Nerval. Bulletin de Méthodologie Sociologique, 28,24-54. DOI: $10.1177 / 075910639002600103$

Roberts, K. (2006). Populism, Political Conflict, and Grass-roots Organization in Latin America. Comparative Politics, 36(2), 1272 1283. DOI: $10.2307 / 20433986$

Rooduijn, M., Lange, S. L., \& Brug, W. V. D. (2014). A Populist Zeitgeist? Programmatic Contagion by Populist Parties in Western Europe. Party Politics, 20(4), 563-575. DOI: 10.1177/1354068811436065

Santaella, L., \& Lemos, R. (2010). Redes sociais digitais: a cognição conectiva do Twitter. São Paulo: Paulus.

Statista. (2021). Leading Countries Based on Number of Twitter Users as of January 2021. Retrieved from www.statista.com/statistics/242606/ number-of-active-twitter-users-in-selected-countries/

Teófilo, S., Lima, B., \& Cardim, M. E. (2021, March, 7). Em recorde de mortes diárias, Governo coleciona falas que minimizam a pandemia. Correio Braziliense. Retrieved from www.correiobraziliense.com.br/ brasil/2021/03/4910658-em-recorde-de-mortes-diarias-governocoleciona-falas-que-minimizam-a-pandemia.html

Vasconcelos, F. (2013). A mídia e o neo-populismo. Revista Compolítica, 3(2), 293-308. DOI: 10.21878/compolitica.2013.3.2.54 
Viscardi, J. M. (2020). Fake news, verdade e mentira sob a ótica de Jair Bolsonaro no twitter. Trabalhos em Linguística Aplicada, 59(2), 1134-1157. DOI: 10.1590/01031813715891620200520

We are Social. (2019, January, 31). SPECIAL REPORT - DIGITAL 2020. Your ultimate guide to the evolving digital world. Retrieved from https://wearesocial.com/uk/blog/2019/01/digital-in-2019-globalinternet-use-accelerates/

Waisbord, S. (2013). Populismo e Mídia: o Neopopulismo na América Latina. Revista Contracampo, 28(3), 26-52. DOI: 10.22409/ contracampo.v0i28.617

CARLA MONTUORI FERNANDES. Postdoctorate in Political Communication from the University of Valladolid (Spain). She holds a PhD in Social Science from the Pontifical Catholic University of São Paulo (PUC-SP). She is a professor of the Graduate Program in Communication at Paulista University. Collaboration in this article: conception and design of the study, acquisition, analysis and interpretation of data; results discussions; manuscript writing; review and approval of the final version of the work. E-mail: carla.montuori@docente.unip.br

LUIZ ADEMIR DE OLIVEIRA. Post-doctorate in Social Communication from the Federal University of Juiz de Fora (UFJF), a PhD (2005) and Master's degree (1999) in Political Science from the Brazilian Society of Instruction - SBI/IUPERJ, and a Master's degree in Social Communication from the Federal University of Minas Gerais (UFMG). Currently he works as a professor and a researcher in the Social Communication course at the Federal University of Juiz de Fora (UFJF). Collaboration in this article: conception and design of the study; results discussions; review and approval of the final version of the work. E-mail: luizoli@ufsj.edu.br 
MARIANE MOTTA DE CAMPOS. Doctoral student in Communication at Paulista University's (UNIP) Graduate Program in Communication. She holds a Master's degree in Communication from the Graduate Program in Communication at the Federal University of Juiz de Fora (UFJF). CAPES scholarship holder. Collaboration in this article: acquisition, analysis and interpretation of data; results discussions; manuscript writing; review and approval of the final version of the work E-mail: marianemottadecampos@hotmail.com

MAYRA REGINA COIMBRA. Doctoral student in Communication at the Federal University of Juiz de Fora. She holds a Master's degree in Communication in the "Communication and Power" line from the Federal University of Juiz de Fora. Capes scholarship holder. Collaboration in this article: acquisition, analysis and interpretation of data; results discussions; manuscript writing; review and approval of the final version of the work. E-mail: mayrarcoimbra@gmail.com

RESEARCH FUNDING: this work was realized with the support of the Coordination for the Improvement of Higher Education (CAPES), financial code 001.

TRANSLATED BY: LEE SHARP

Two reviews used in the evaluation of this article can be accessed at: https://osf.io/6q83m/ and https://osf.io/2mgpn/ | Following BJR's open science policy, the reviewers authorized this publication and the disclosure of his/her names. 